\title{
What Can Latin America Learn from China's Labour Market Reforms?
}

\section{Citation}

Richard B. Freeman. 2014. What can Latin America learn from China's labour market reforms? In Falling Inequality in Latin America: Policy Changes and Lessons, edited by Giovanni Andrea Cornia, 274-294. Oxford: Oxford University Press.

\section{Published Version}

10.1093/acprof:oso/9780198701804.003.0013

\section{Permanent link}

http://nrs.harvard.edu/urn-3:HUL.InstRepos:34548955

\section{Terms of Use}

This article was downloaded from Harvard University's DASH repository, and is made available under the terms and conditions applicable to Open Access Policy Articles, as set forth at http:// nrs.harvard.edu/urn-3:HUL.InstRepos:dash.current.terms-of-use\#OAP

\section{Share Your Story}

The Harvard community has made this article openly available.

Please share how this access benefits you. Submit a story.

Accessibility 


\section{What Can Latin America Learn from China's Labour Market}

\section{Reforms?}

\section{Richard B. Freeman}

Analysts typically take the labour institutions in advanced countries as defining the ways in which developing economies can organize their labour markets. International agencies often pose the choice as one between a US-style decentralized market-driven system that relies on employers to determine wages and working conditions subject to market pressures with little institutional intervention or collective bargaining; or a European Union (EU)-style system in which industrial or regional unions bargain collectively with employer federations to produce agreements that governments may extend to all firms and workers in the sector. The IMF and World Bank favour US-style labour flexibility. The ILO favours EU-style bargaining.

In this chapter I argue that developing-country labour markets differ so much from those in advanced countries that developing countries can benefit more from the experience of the labour markets in other developing countries than from the labour markets of the USA and EU. I examine the range and performance of labour institutions among advanced and developing countries. I then compare China's labour institutions and labour market reforms to Latin American institutions and reforms (as analysed inter alia by Keifman and Maurizio in Chapter 12) and use this as my case in point of what developing countries can learn from each other's labour experiences, the similarities and differences in how Latin America and China have dealt with the same types of labour problems. 
Labour issues in developing economies differ from those in advanced economies in three fundamental ways. First, the informal share of the labour force is far greater in developing countries than in advanced countries. Throughout the developing world, many workers are self-employed, and many work as employees in the informal sector or in informal jobs within the formal sector (see Section 2.2 of Chapter 12). From 40 per cent to 90 per cent of the labour force in developing countries works with few formal-sector rights or protections. By contrast, about 5 to 10 per cent of the labour force in advanced countries works in the informal sector or in informal jobs. ${ }^{1}$ The inverse relation between the proportion of informal workers and level of development suggests that economic growth shifts labour from generally precarious low-paid informal jobs to more desirable formal-sector jobs. But time-series data show little decline in the informal share of employment in most developing countries even when they experience rapid economic growth. Increasing levels of GDP per capita did not reduce the informal sector's share of employment in India and China between the 1980s and 2010s. Economic growth in Latin America and Southeast Asia from the mid-1980s to the mid-1990s was associated with a shift in the work force towards the informal sector (OECD 2009: Figure 0.1). Table 2.3 of this book shows a continued decrease in the percentage of formal-sector workers in Latin America from 55.0 per cent in 1990 to 50.7 per cent in 2009. Perhaps most telling, despite Korea's extraordinary economic success, the proportion of workers categorized as

\footnotetext{
1 The proportion of workers with non-standard or irregular contracts has increased in advanced countries but most of these workers still have some protections and social insurance and pay charges for those benefits.
} 
non-standard or irregular, including temporary or day workers, contingent workers, and so on, increased from 1996 to 2006 (Lee and Lee 2007; Grubb, Lee, and Tergeist 2007).

Table 13.1 compares informal employment in the non-agricultural sector for Latin America and China. Column 1 summarizes data from the OECD study Is Informal Normal? (which concluded that yes it was) on the informal sector's share of employment in Latin American countries in the 1990s. Column 2 gives estimates of informal employment in Latin America for 2009/latest year from the ILO’s (2011) 'Statistical Update on Employment in the Informal Sector'. The full datasets, which contain additional countries, show that the informal sector's share of employment is lower in countries with higher GDP per capita. But using the difference between the estimated shares of informal-sector employment in columns 1 and 2 as an indicator of trends over time, there is no evidence of trend declines in the informal sector's share of employment: the informal share increased in eight countries and fell in four countries. Because 'the official statistical apparatus in China still does not gather systematic data on the informal economy', ${ }^{2}$ I rely on academic researcher estimates of the informal sector for China in the bottom row. Retrenchment of state-owned enterprises in the 1990s and massive flow of migrant labour in the 1990s-2000s into urban areas raised the informal sector's share of non-agricultural employment substantially in that country.

Labour regulations can reduce the movement of workers from the informal to the formal sector (Djankov 2009) but do not explain much of the long-term persistence of

2 Huang (2009: 45). Cooke (2008: 4) reports that the term 'informal employment', however, is a relatively new concept in China that was first introduced by the labour authority in Shanghai in 1996. 
informal-sector employment. Mobility of workers between formal and informal jobs is high in Latin America (Perry et al. 2007) and possibly elsewhere, but much of the movement is cyclic. Informal-sector workers move to formal jobs when the economy booms and return to the informal sector when it contracts. Underlying the continued importance of informal-sector work in developing countries is the rapid growth of productivity in manufacturing and industry (where formal-sector work predominates), which limits job growth in those sectors, and the slower growth of productivity in the service industries (where informal-sector work predominates).

With a substantial share of the labour force working outside the formal sector for the foreseeable future, developing countries have to devise new ways to deliver pensions, occupational health and safety protection, unemployment insurance, training, labour rights, and other social services to informal sector workers or face continued bifurcation of their labour markets into a better paid protected formal sector and a lower paid informal sector.

[Insert Table 13.1 about here]

The second big difference between labour in developing economies and in advanced economies is that developing economies have greater inequality in household income and in labour earnings. Column 1 of Table 13.2 documents the level of income inequality with Gini coefficients from the Central Intelligence Agency's The World Factbook. The column records the median Gini coefficient from the distribution of Ginis for advanced countries and the median Gini from the distribution for all other countries. It also gives Gini coefficients for selected advanced countries, for China, and for Latin American $^{3}$ countries. The median Gini for advanced countries is 30.9 compared to 40.9 3 I include some Caribbean countries under the Latin American heading. 
for 'other countries'. ${ }^{4}$ The USA's 45.0 Gini makes it the only major advanced country with a developing-country level of inequality.

[Insert Table 13.2 about here]

Latin American countries have historically had high inequality. The median Latin American Gini was 51.0 in the late 2000s despite the decline in inequality of income over the previous decade (Cornia 2010). Ginis vary in Latin America from 41.0 in Venezuela to 58.5 in Colombia but every Latin American country is above the median for developing countries.

China's Gini of 41.5 places it in the middle of the distribution for all countries and below the Ginis of nearly all Latin American countries. Before China began its economic reforms it had the narrow distribution of incomes associated with communist economies. Market-oriented reforms doubled the Gini in China between 1978 and the 1990s. Inequality continued to increase into the 2000s (Chen et al. 2010). Much of China's rising inequality is associated with urban-rural differentials which trended upwards as economic reform brought market wage-setting to the urban areas. In 2010 the urban-rural income differential reached an all-time high of 3.33 to 1 . Viewing Gini coefficients in the Latin American range as dangerous to social stability, the Chinese government has adopted labour market and social policies designed to shift the distribution of income towards lower-wage workers and lower-income families.

The third big difference between labour in developing countries and advanced countries is in the distribution of skills among workers. Most developing-country labour 4 I distinguish between advanced economies and all others, including wealthy Arab oil countries, transition economies, and so on for simplicity. Comparisons are qualitatively similar for more narrowly drawn samples of economies. 
forces contain a rapidly growing population of highly educated younger persons in urban areas, a population of less educated older persons, and a large number of young persons in rural areas who drop out of school at an early age. This dualistic structure is far wider than the distribution of education in advanced countries today and wider than the distribution in those countries when they were experiencing their growth spurts. The reason is that from the end of the twentieth century to the 2010s developing countries invested more heavily in higher education and graduated relatively more people with university degrees at an earlier stage of development than countries have ever done before (Freeman 2010, see also Chapter 15). Table 13.3 shows data on enrolments and degrees in tertiary institutions in the USA, China, and Latin America in 2007. China had the largest number of students and graduates in the world—enrolling over 25 million students in tertiary education and graduating 5.9 million with bachelor's degrees-the result of expanding mass higher education following the virtual closure of the university system in the Cultural Revolution. US and Latin American undergraduate enrolments were about 75 per cent of Chinese enrolments but the number of US graduates was less than 50 per cent of Chinese graduates and the number of Latin America's graduates was just 37 per cent of Chinese graduates. ${ }^{5}$ In addition to enrolling large numbers in domestic colleges and universities, developing countries send an increasing number of students for

5 The gap between graduates and enrolments in the USA results from the high proportion of US students enrolled in community colleges, where many obtain the associate's degree as a final degree. The gap in Latin America reflects the fact that many students take a long time to get their degrees and many also do not complete their education. 
study in the advanced countries. ${ }^{6}$ Relative to population, the Chinese obtain nearly twice as many PhDs in the USA as do Latin Americans.

The large increasing supply of graduates in developing countries gives those countries the capacity to 'leapfrog' to the forefront of modern technology and compete with advanced countries in high-tech sectors which economists once viewed as the comparative advantage preserve of the advanced countries. In the labour market, the increased supply of graduates drives down the wage advantage of educated workers, which reduces inequality. In the case of China, Cai Fang and Wang Meiyan (2010) estimate that between 2003 and 2009 the earnings advantage of starting college graduates in China fell relative to the earnings of migrant workers from 2.25 to 1.65 . But a higher share of the work force with university education can also add to inequality by increasing the proportion of workers with above-average wages and, given the above-average levels of within-group inequality among college graduates, by increasing the proportion of workers from a high within-group level of inequality. Perhaps most important, the number of graduates increased so rapidly in China from the 1990s to the 2010s as to create a huge disconnect between the career aspirations and earnings expectations of graduates and employment prospects available to them in an economy with a large informal sector. Since a disconnect among the educated young can readily erupt into social disorder, Chinese leaders gave priority during the great recession to finding jobs for university graduates as well as for the displaced migrant workers.

6 Of the $49,562 \mathrm{PhDs}$ granted in the US in 2009 , one-third $(14,567)$ went to the foreign-born, with students from mainland China obtaining 4,100 PhDs. Latin Americans earned 1,065 PhDs, of whom 20 per cent were from Mexico (NSF 2012: Tables 40, 49). 
Having substantial numbers of university graduates and less skilled informalsector workers in the same economy requires developing countries to have labour policies that deal not only with the traditional labour-relations issues pertaining to formal-sector industrial workers per advanced country labour law and institutions but also to develop policies for the labour market for university graduates and for informal-sector workers as well.

\section{Labour Institutions}

Think-tanks, international agencies, and independent researchers provide measures of the institutional differences among countries in the form of readily available indexes of economic freedom, competitiveness, business climate, etc. ${ }^{7}$ The organizations that construct these indexes generally take an ideal competitive market as the benchmark for assessing economies. Thus they treat reliance on market forces as a positive attribute of a labour system and treat collective bargaining and other institutional processes for setting pay or employment as a negative attribute. The indexes put countries whose institutions resemble those of the USA and other Anglo-American economies (Freeman, Boxall, and Haynes 2007) above countries with EU-style institutions. But the orientation does not distort assessments of where a country's labour institutions lie on a scale from primarily market-driven to primarily institution-driven (Chor and Freeman 2005). Analysts who favour EU-style institutions can simply 'reverse code' the ratings so that instead of

\footnotetext{
7 Among the many such measures are the Fraser Institute's Economic Freedom index, the Heritage Foundation Wall Street Journal Economic Freedom index, the World Bank's Doing Business indicators, and the World Economic Forum's Global Competitiveness indicators.
} 
reporting that countries with an institutional bent rank low on a market-freedom scale, they can report that they rank high on an institution-oriented scale. ${ }^{8}$

Column 2 of Table 13.2 gives the ranking of countries by labour market regulations from the Fraser Institute index of economic freedom. Fraser scores the labour regulations in 140 countries on the basis of hiring regulations and minimum wage, hiring and firing regulations, centralized collective bargaining, hours regulation, mandated cost of worker dismissal, and conscription. Indicative of Fraser's preference for market solutions, the 2009 rating placed the USA fifth in economic freedom in the labour market (i.e. having few regulations), far above Sweden at 107 and Germany at 112 . The Fraser labour regulation index ranked China at 103. The ranking for Latin American countries varied widely. Fraser gave Haiti the number one spot in its index as having the least regulated labour market in the world. By contrast, it placed Brazil at 130 in its ranking for having extensive labour regulations. The median ranking of 108 for Latin American countries puts the continent high in labour market regulations.

On average, the Fraser rankings for labour regulations differ only modestly between advanced economies and other economies while differing substantially within the groups. One interpretation of this pattern is that development does not select any particular institutional structure for regulating the labour market. Countries have

$8 \quad$ To reverse code a rating system one simply subtracts the ratings from the sum of the highest and lowest values of the scale. To reverse a code or a scale that rates countries from 1 (least regulated) to 5 (most regulated) to a scale that rates countries in the opposite direction, subtract the rating from 6 . 
considerable leeway or choice in structuring their labour institutions. They can be Sweden or the USA . . . or Haiti or Brazil.

But while labour institutions have no noticeable relation to the level of economic development, institutions are closely related to the distribution of earnings and income, as argued also in Chapter 12. Studies invariably find that the greater the extent of trade unionism or collective bargaining the lower is the level of inequality. Countries with greater union density or with more centralized or coordinated collective bargaining have lower dispersion of earnings among advanced countries (OECD 2004: Chapter 3) and among all countries (Freeman and Oostendorp 2000). Studies that examine particular economies over time find a similar pattern: when union density/collective bargaining coverage increases, inequality tends to fall, and when unionism/bargaining coverage falls, inequality increases (OECD 2011: Table 2). In its 2013 World Development Report, the World Bank summarizes its review of the evidence:

It is also clear that unions and collective bargaining have an equalizing effect on earnings distributions by compressing wage differentials. Research has shown that wage inequality falls during periods when union density is increasing and rises when union membership is in decline (World Bank 2013: 263).

The remaining columns of the table record the rankings of countries by three criteria from the 2011-12 World Economic Forum's Global Competitiveness Report (GCR). The GCR scores countries on the basis of its annual Executive Opinion Survey of executives in each country and on relevant objective data from national or international sources. The 
2011-12 survey was based on 13,395 responses from executives, giving an average of 98 respondents per country (WEForum 2011: 75).

The labour efficiency measure in column 3 is a composite index that combines the answers to nine questions. Four of the questions enter the Fraser index: flexibility of wage determination; rigidity of employment; hiring and firing practices; and redundancy costs. The other questions ask about: cooperation in labour-employer relations; the link between pay and productivity; reliance on professional management; brain drain; female participation in the labour force. The GCR ranks the USA fourth in efficiency, nearly identical to the Fraser Institute ranking of the USA in terms of labour regulations. But the additional factors in its measure of labour efficiency place Germany, Sweden, and China higher in the GCR scale than in the Fraser labour regulation scale. Germany and Sweden rank high in cooperation in labour relations, reliance on professional management, and brain drain (they gain rather than lose from it). China has a higher rating because executives view China as being high in linking pay and productivity and in other dimensions with the noticeable exception of regulations—-where executives score poorly on rigidity in employment decisions and required severance pay in lay-offs. While Latin American countries evince wide differences in GCR ratings, every Latin American country has a lower score in labour market efficiency than China. The Fraser number 1 country, Haiti, rates near the middle of the ratings in labour efficiency. In the eyes of executives the only thing that Haiti does right in the labour area is to provide limited or weak regulations for workers.

Column 4 gives the country rankings by 'higher education and training'. This is a composite measure that includes sub-indexes for producing qualified university-level 
labour, including secondary school enrolments and quality of mathematics education. The advanced countries score well on this indicator. Sweden and Germany rate higher than the USA. China scores above the median Latin American country but falls short of the advanced countries. China's huge expansion of higher education came at the cost of the quality of education.

Column 5 ranks countries by the 'capacity for innovation'. This composite is based on indicators of the supply and deployment of science and engineering graduates and investments in research and development: availability of scientists and engineers; quality of scientific research institutions; company spending on R\&D; universityindustry collaboration in R\&D; and government procurement of advanced tech products. The USA, Germany, and Sweden rank high in these areas. Latin America scores poorly. The highest ratings for innovation in Latin America are for Brazil, Chile, and Costa Rica. China rates closer to the advanced countries on the innovation measure than it does on any other metric and exceeds all of the Latin American countries. In the 2000s China made huge investments in doctorate education and in $R \& D$, which brought it to the frontier of knowledge creation in various areas. The Chinese share of scientific papers is on a sharp upward trajectory.

Overall, Table 13.2 shows that developing countries differ more from advanced countries in the three GCR indicators than in the Fraser Institute labour regulation index. The traditional debate over labour policies—decentralized markets US-style versus collective bargaining and institutional interventions in the labour market EU-style—that the Fraser index measures does not capture the fact that developing countries differ most 
from advanced countries in a broader labour space that includes the operation of the higher educational system, the graduate job market, and openness to innovation.

\section{[Insert Table 13.3 about here] \\ 3 Institutions and Outcomes}

If the labour markets of advanced countries performed markedly better than those of developing countries, it might make sense for developing countries to seek to follow the models of the advanced countries even though the labour situation in developing countries differs greatly from that in the advanced countries.

The great recession of 2008-09 and ensuing recovery tested the performance of labour markets worldwide. At the outset of the crisis, many analysts feared that workers in developing countries would suffer massively from the global recession. When the recession hit China in winter 2009 and South China factories laid off 20 million migrant workers, who returned to their villages, it appeared as if the contraction in global trade was going to devastate the Chinese economy. Past global recessions had caused great harm in Latin America, raising fears that the recession would undo the economic gains of the previous decade. Among the advanced countries, many believed that the marketdominated labour system of the USA would fare better than the institution-driven labour markets of advanced Europe.

What happened was quite different. Employment proved to be more resilient in developing countries than in advanced countries. China recovered within a year and went on to experience rising wages and employment in 2010 and 2011. In Latin America employment fell less and recovered more quickly than in advanced OECD countries. One reason was that the informal labour markets in developing countries buffered job loss. The ILO estimates that when the recession cut formal-sector employment from Q2 2008 
to Q2 2009 in six Latin American countries, there was a near commensurate increase in informal-sector employment (ILO 2010: Figure 1.7). Another reason was that Latin American GDP recovered quickly: in 2009 GDP per capita contracted by 2.9 per cent, but GDP per capita then increased by 4.2 per cent in 2010 - 7.1 percentage point turnaround. ${ }^{9}$ Among advanced countries also, the responses to the recession and recovery differed from prior expectations. The USA shed jobs quickly, due to its flexible labour market, but restored jobs slowly in the ensuing recovery and experienced a substantial increase in the length of spells of joblessness. Denmark, whose widely heralded 'flexicurity' policy relied on flexible hiring and firing strategies, also had a disappointing employment recovery. By contrast, Germany's job-sharing policy maintained employment well, and other EU countries that relied extensively on institutions, such as Austria, the Netherlands, and Sweden, also did well.

There are lessons for developing countries from the experiences of the advanced countries with different labour institutions, but the overall performance of advanced countries in the great recession and its aftermath does not suggest that those countries have the answers to the labour issues facing developing countries. On the notion that developing economies can learn more from their own experiences and the experiences of other developing countries than from the experiences of advanced countries, I consider next some of the policies that China adopted to deal with its labour problems, compare them to policies in Latin America, primarily Brazil, and then consider what Latin America can learn from China and what China can learn from Latin America.

\subsection{China's New Labour Policies}

9 See the CEPAL figures cited in Chapter 2 of this volume. 
Increased inequality has long troubled China's leadership. In 1998 Jiang Zemin warned that 'if certain social and economic problems are not tackled without delay, the overall stability of the country could be threatened' ${ }^{10}$ In 2007 President Hu Jintao declared that the government intended to 'increase transfer payments, intensify the regulation of incomes through taxation, break business monopolies, create equal opportunities, and overhaul income distribution practices with a view to gradually reversing the growing income disparity'. ${ }^{11}$ In March 2011 Premier Wen Jiabao pledged help to farmers and the urban poor to contain growing social dissatisfaction.

The concerns of the top leaders are rooted in reality. Social protests and wildcat strikes have become endemic in China. The number of labour disputes that workers brought to the Labour Dispute Arbitration Committees (the legal bodies set up to resolve disputes) increased from 47,951 in 1996 to 693,000 in 2008 and purportedly reached 1,280,000 in $2010 .{ }^{12}$ The summer 2010 strike by Honda workers made headlines around

10 See China Daily (13 January 1999) reporting on a speech given by President Jiang Zemin on 24 December 1998 at a national conference on China's legal and political situation, in which President Zemin highlighted social stability as the most important task for China in 1999.

11 Address to the 17th National Congress of the Communist Party of China (15 October 2007). The full text can be found at: www.aboutxinjiang.com/topic/content/2011-06/27/content_5925466_9.htm 12 China Labour Bulletin (2009) for figures up to 2008, and China Daily (2011) for the 2010 figure. 
the world. Indeed, the number of strikes in China has grown so rapidly that a website now maps them across the country based on news articles and other reports. ${ }^{13}$

The government's response to the perceived threat of inequality has been to: (i) strengthen the legal rights of informal workers; (ii) raise minimum wages and transfer payments, (iii) seek to transform the country's 'transmission belt' trade unions into something closer to a genuine representative of workers; and (iv) strengthen mediation and arbitration.

To help informal workers, China enacted a contract labour law that took effect on 1 January 2008. The law required that employers give migrant workers a written contract, which workers could take to court or arbitration committees to obtain their rights. Opponents of the law claimed that it would reduce competitiveness and recreate the "iron rice bowl' ${ }^{14}$ labour conditions that had existed under state planning. Representatives of the All China Federation of Trade Unions (ACFTU) and academic experts on labour relations claimed that it would improve the labour market and channel discontent away from wildcat strikes or other protests.

The new law also increased the formal rights of informal workers. It limited probationary periods to two years, gave workers with ten years' experience with a firm permanent contracts, allowed dismissal only on just-cause grounds, required firms to pay

\footnotetext{
13 China Strikes, see www.chinastrikes.crowdmap.com/main

14 This is the phrase used to refer to the system of guaranteed lifetime employment and benefits in state-owned enterprises in which management could not fire workers and workers could not switch jobs, and where the enterprise paid wages and benefits set by the state.
} 
one month severance pay for each year of work, and allowed workers to refuse dangerous work. It further required that employers consult with unions on changes in rules, that they concur with local industry-wide agreements in some sectors, and it gave employees the right to elect representatives for bargaining if the official ACFTU union did not represent them. Further, it raised the fines for breaking the law.

Did the law have its desired effect? Xiaoying Li and I (Freeman and Li 2012) examined this question using surveys of migrant workers in the Pearl River Delta before and after the law took effect. Our main finding was that the law was effective. As Table 13.4 shows, from 2006 to 2009 the percentage of migrants with contracts increased, as did the percentage covered in social insurance programmes, while fewer workers reported violations of their rights. To strengthen the law, in February 2011 China made it a criminal offence for companies to intentionally withhold employee pay if it has money to pay or if it transfers assets to escape paying.

\section{[Insert Table 13.4 about here]}

As occurred in Latin America during the last decade (see Chapter 12), China's Ministry of Human Resources and Social Security has set since 2004 a national minimum wage to cover town and village enterprises, employees in small private businesses, and part-time workers. But the more important minimum wages are set by local and provincial governments, which often set a minimum far above the national ministry level. The level of the minimum varies greatly across Chinese cities. In 2007 the monthly minimum ranged from 430 yuan in Gansu in the west to 850 yuan in Zhejiang, Jiangsu, and Guangdong in the east (Wang and Gunderson 2011: Table 1). To increase earnings at the lower parts of the income distribution, Chinese provinces and municipalities raised minimum wages substantially in 2011. Over half of the 12 municipalities and provinces 
in China raised their minimum wages by over 20 per cent. The average minimum in the eastern and southern provinces exceeded 1,000 yuan. Zhejiang enacted a 1,310 yuan minimum, a 19 per cent increase over its 2010 level. Even Hong Kong, whose freemarket orientation has produced one of the least regulated labour markets in the world, introduced a minimum wage in 2011.

Researchers have not studied distributions of pay before and after the changes in the city or province minimum, nor examined whether increases in minimum wages spread from covered workers to others. It is clear, however, that workers are aware of the minimum wage in China. One contributing factor to the summer 2010 Honda strike was that the firm sought to evade an increased minimum in Foshan City by lowering meal and living subsidies by the same amount as the minimum wage increase.

Trade unions are the traditional labour institution through which workers defend their interests in market economies. China's official union organization, the ACFTU, nominally has more members than any other union federation in the world. But most workers do not view their workplace union as representing them. The ACFTU has operated as a Leninist 'transmission belt' organization that supports state policies and promotes workplace cooperation with management rather than acting as a defender of worker interests. It 'organizes' unions by asking management to set up a union in a plant. If management accedes to the request it will often appoint a mid-level manager such as a human-resource executive as union leader. Indicative of this orientation, a senior ACFTU official seeking to unionize multinationals told executives that there was no reason to worry about unionism because 'unlike western unions, which always stand against the employer, Chinese unions are obliged to boost the corporation's development and 
maintain sound labour relations' (cited in Guardian 2011). The labour law requires that companies give 2 per cent of total payroll to the union for its activities, but most firms give much less.

This model of unionism cannot survive in a China where workers are prepared to strike and protest on their own. Recognizing this, the government has allowed the official unions to begin to act more as the representative of workers. The commentary on the Honda strike by Chen Weiguang, Chairman of the Guangzhou Federation of Trade Unions and Vice Chairman of the People's Congress of Guangzhou, represents this new attitude:

The workers did not accept the trade union as their representative ... As the strike went on, the union wavered between management and the workers, and it saw itself as a mediator. Standing between the two sides is the worst position . . . In the labour conflicts at Honda's suppliers . . . in the Nansha district, our approach was very different and the trade union behaved proactively ... we have educated the trade union cadres that they must represent the workers and not play the middleman. In the event of a strike, even very short ones, the trade unions have to be on the side of the workers. $^{15}$

In summer 2011, Hong-Kong-based Han Dongfang, the leading voice for independent unions in China, called on the international union movement to help the ACFTU reinvent itself as a genuine union:

15 Interview with Chen Weiguang, 27 October 2010. 
Constructive engagement with the ACFTU at this point in history could produce real benefits ... If the ACFTU can show it can better serve the party's interests (ensuring economic growth and social stability) by standing up for the rights and interests of workers, the party will certainly take note (cited in Guardian 2011).

US unions, which traditionally shunned the ACFTU as a government bureaucracy, began meeting with ACFTU officials. Reformers in the ACFTU have tried different strategies to position local unions on the side of workers. The Beijing ACFTU central organization appoints union officials who do not work for a company to represent workers in bargaining. Shanghai union officials have endorsed worker elections of local officials. Chen Weiguang's statement above reflects the changed orientation in Guangzhou.

To deal with the increased number of labour disputes, in 2012 China introduced new regulations for labour mediation and dispute resolution. The new regulations sought to strengthen the ability of firms and workers to solve disputes, and thus prevent issues from reaching the labour dispute arbitration commission or producing mass protests or strikes. They required that every large/medium-sized enterprise establish a labour dispute mediation committee comprised of equal numbers of enterprise and worker representatives to facilitate enterprise-worker communications, and to negotiate and resolve labour disputes. The committees hire mediators to help reach a solution and to publicize laws, regulations, and policies related to labour-rights protection. The law further required a written statement signed by both parties to enforce implementation of the resolution. 
Finally, to help move China to the forefront of modern science and technology, China encourages the country's best and brightest to become international students. It awards scholarships for overseas studies, and seeks to gain top graduate students' admissions in leading overseas universities, despite the likelihood that many will settle in advanced countries. The existence of a substantial diaspora population creates an ethnic network through which information about modern technology and practices flows more quickly, thus benefiting the immigrants' home country.

\subsection{Latin American Labour Policies}

In the 1990s Latin America led the world in 'Washington Consensus' reforms to jumpstart economic growth. Argentina became the poster child of the IMF and the Clinton administration for Washington-Consensus-style globalization. Using the Fraser Institute measure of economic freedom, Argentina raised its ranking from 97 in 1985 to 32 in 2000 , one of the largest changes ever in the index. In addition to pegging the peso to the dollar, Argentina deregulated markets, privatized industries, reduced tariffs, lowered taxes on the wealthy, overhauled its pension system towards a defined-contribution system, and so on. ${ }^{16}$ Many other Latin American countries chose similar labour and social assistance policies. They moved from defined-benefit to defined-contribution pensions (Barrientos and Hinojosa-Valencia 2009; Chapter 16: Figure 16.1), privatized some government-run businesses, and reduced employment protection to increase labour flexibility. Union representation fell in most of Latin America. Inequality increased. The proportion of workers in the informal sector rose. In Brazil, conservative governments

16 Data for Argentina from the Fraser Institute, available at: <http://www.freetheworld.com/2011/reports/world/EFW2011_chap2.pdf> 
sought to undo or weaken the labour protections/rigidities built into the 1988

constitution. ${ }^{17}$ They ended the indexation of wages to consumer prices and allowed inflation to reduce the real value of the minimum wage by over a third from 1990 to 1995.

But the market-oriented reforms did not deliver on their promise of better functioning economies. Latin American economies that adopted the market reforms did not experience any spurt in economic growth. Argentina, which had high unemployment and rising inequality even as its GDP grew in the early and mid-1990s, fell into recession in 1999. The 2002 collapse of the Argentine peso put the finishing touches on the failed Washington Consensus model of growth (Hornbeck 2002).

In the 2000s most Latin American countries shifted policies to fight inequality and poverty. Brazil was the exemplar of the new orientation. It developed a set of antipoverty programmes targeted at the very poor, such as the Balsa Familia cash transfer programme that gave financial support to about one-quarter of the population, a rural pension scheme that provided benefits to rural workers, the Beneficio de Presetacao Continuada programme that provided social assistance to the elderly poor and disabled, and other programmes as well. Targeting funds at persons in greatest need reduced poverty and inequality, even though the programmes were a relatively small share of GDP. Reversing the 1990-95 reduction in the real minimum wage, Brazil raised the minimum wage faster than inflation, doubling the real minimum between 2000 and 2010 .

17 For instance, by allowing workers/firms to form worker cooperatives to work for firms outside of the employment laws, by allowing workers/firms to bank hours worked, which would avoid overtime pay. 
The Brazilian minimum generally spills over to social assistance payments and earnings elsewhere in the economy. It induces increased wages for informal workers not covered by the minimum through what is called the El Farol or lighthouse effect. Analysts attribute approximately two-thirds of the fall in inequality to the increased minimum (Berg 2011).

Over the same period, Brazil's economy boomed and the share of the workforce in the informal sector declined by 6 to 10 percentage points (as indicated in Table 13.1). ${ }^{18}$ Brazil increased its spending on enforcing labour regulations, with discernible effects on the level and location of employment and wages (Almeida and Carneiro 2007). It instituted policies that promoted formalization beyond the flow of informal-sector workers to the formal sector in economic booms. To improve the incentives for small firms and micro-enterprises to formalize, the government enacted the SIMPLES law that exempted small firms from taxes and made it less costly for them to formalize. It also gave labour inspectors incentives to register informal workers and to help firms deal with the problems that might arise from formalization (Pires 2008).

\section{Towards New Labour Institutions and Policies}

China and the Latin American countries have to overcome similar problems to grow their economies for the benefit of the bulk of the population. They have to find ways to improve the economic wellbeing of informal-sector workers, to reduce or at least arrest the growth of income inequality, and to balance the increased supply of university graduates with the development of knowledge-based industries.

18 Berg (2011: 7-8 and Figure 2). 
There are similarities and differences in the ways in which China and Brazil and other Latin American countries have dealt with these problems. The biggest similarity is in the commitment of governments to policies that spread the benefits of economic growth to workers and throughout the income distribution. The rhetoric in China contrasts with the early days of Chinese reforms when in 1985 Deng Xiaoping famously said 'let some people get rich first'. The rhetoric in Latin America contrasts with the 1990s Washington Consensus policies.

China and Latin America rely extensively on minimum wages to help ensure that the wages of lower-paid workers increase as the economy grows. China's local determination of minimum wages creates extraordinarily wide within-country variations in the minimum, though the range of minimum wages across all Latin American countries may approach that among Chinese provinces and cities.

What at first look seems to be the biggest difference between the efforts of China and Latin America to improve the incomes of workers is that China seeks to empower workers and unions whereas Brazil and other Latin American countries rely more on state initiatives, such as Brazil deploying its labour inspectorate to encourage firms to move into the formal sector and giving firms tax incentives to do so (Almeida and Carneiro 2011). Brazil has also built up knowledge of how to manage the inspectorate to carry out their jobs (Pires 2011). But this difference is less striking in the light of China's official unions being part of the government/party apparatus. China's union cadres are more like labour inspectorate officials than independent representatives of workers.

China's decision to empower workers and strengthen collective bargaining may seem paradoxical given the role of the communist party and government in China's 
version of state capitalism (Economist 2012). It reflects the division of power and incentives between a central government committed to reduce inequality and local authorities committed to expanding local business. It also reflects a belief that relying on workers and unions to defend worker rights strengthens social stability by channelling discontent to the private market rather than towards the state. This in turn allows the government to play the mediating role.

One other difference between the policies of China and Latin America deserves attention. China has been far bolder in building up its university graduate workforce and investing in R\&D than has any Latin American country. Along with its policy of increasing the supply of university students, China raised R\&D spending in the 2000s so rapidly that it became the second largest investor in R\&D in the world (the USA being the lead country). China's R\&D to GDP ratio increased to nearly twice that of Brazil, Latin America's leader in R\&D (NSF 2012: Table 4.19).

Latin American analysts and decision-makers have much to learn from China's effort to give workers the legal status and tools to defend their rights, particularly in light of modern information and communication technology, its efforts to build up collective bargaining, and its investments in higher education and R\&D. China has much to learn from the Latin American experience with formal labour inspectorates enforcing labour regulations and the informal El Farol spreading the effects of minimum wages. Paying increasing attention to the institutions and policies of the other is likely, in my view, to give each a higher pay-off in knowledge about ways to improve labour policies than each continuing to look primarily at what the advanced countries are doing in their labour markets. 


\section{References}

Almeida, R. and P. M. Carneiro (2007). 'Inequality and Employment in a Dual Economy: Enforcement of Labour Regulation in Brazil'. IZA Discussion Paper 3094. Bonn: Institute for the Study of Labour.

Almeida, R. and P. M. Carneiro (2011). 'Enforcement of Labour Regulation and Informality'. IZA Discussion Paper 5902. Bonn: Institute for the Study of Labour.

Barrientos, A. and L. Hinojosa-Valencia (2009). 'A Review of Social Protection in Latin America'. Centre for Social Protection, Scoping Study (June). Available at: www.ids.ac.uk/files/dmfile/SocialProtectioninLatinAmerica.pdf

Berg, J. (2011). 'Laws or Luck? Understanding Rising Formality in Brazil in the 2000s'. In S. Lee and D. McCann (eds), Regulating for Decent Work. New Directions in Labour Market Regulation. Geneva: ILO.

Chen, J., D. Dai, M. Pu, W. Hou, and Q. Feng (2010). 'The Trend of the Gini Coefficient of China'. BWPI Working Paper 109. Manchester: Brooks World Poverty Institute, University of Manchester.

Chen, W. (2010). Interview 27 October. Berkeley, CA: UC Berkeley Labor Center. Available at: http://laborcenter.berkeley.edu/global/CWG_interview.pdf

China Daily (2011). 'More Arbitrators Needed as Labour Disputes Soar'. 9 June. Available at: www.chinadaily.com.cn/china/2011-06/09/content_12662445.htm. China Labour Bulletin (2009). 'China’s Labour Dispute Resolution System'. Available at: www.clb.org.hk/en/node/100618. 
Chor, D. and R. B. Freeman (2005). 'The 2004 Global Labour Survey: Workplace Institutions and Practices around the World'. NBER Working Paper 11598. Cambridge, MA: National Bureau of Economic Research.

Cooke, F. L. (2008). 'Labour Market Regulations and Informal Employment in China: To What Extent Are Workers Protected?'. Paper presented at the Third China Task Force Annual Meeting, 25-26 June. Manchester.

Cornia, G. A. (2010). 'Income Distribution under Latin America's New Left Regimes'. Journal of Human Development and Capabilities, 11(1): 85-114.

Djankov, S. (2009). 'Symposium: Labour Regulation in Developing Countries'. Journal of Comparative Economics, 37(1): 1-194.

Economist, The (2012). Special Report: State Capitalism. 21 January. Available at: media.economist.com/sites/default/files/sponsorships/MM150/20120121_state_ca pitalism.pd.

Fang, C. and M. Wang (2010). 'Four Topics on Wage Changes in the Chinese Economy'. Paper presented at the Pacific Trade and Development Conference 'China's Role in the World Economy', 6-9 December. Available at: www.paftad.org/files/34/03_FANG_Distortions.pdf.

Fraser Institute $(2009,2011)$. Economic Freedom of the World, Annual Report. Vancouver: Fraser Institute. Available at: www.freetheworld.com/release.html. Freeman, R. B. (2010). 'What Does Global Expansion of Higher Education Mean for the United States?'. In C. Clotfelter (ed.), American Universities in a Global Market. Chicago: University of Chicago for NBER. 
Freeman, R. B., P. Boxall, and P. Haynes (2007). What Workers Say: Employee Voice in the Anglo-American Workplace. Ithaca, NY and London: ILR Press.

Freeman, R. B. and X. Li (2012). 'How Does China's New Labour Contract Law Affect Floating Workers?'. NBER Working Paper, July. Cambridge, MA: National Bureau of Economic Research.

Freeman, R. B. and R. Oostendorp (2000). 'Wages around the World: Pay across Occupations and Countries'. NBER Working Paper 8058. Cambridge, MA: National Bureau of Economic Research.

Ghose, A. K. (2005). 'Employment in China: Recent Trends and Future Challenges'. Employment Strategy Papers 2005/14. Geneva: ILO.

Grubb, D., J.-K. Lee, and P. Tergeist (2007). ‘Addressing Labour Market Duality in Korea'. OECD Social, Employment and Migration Working Paper 61. Paris: OECD.

Guardian, The (2011). 'China's Main Union Is Yet to Earn Its Job'. 26 June. Available at: www.guardian.co.uk/commentisfree/2011/jun/26/china-trade-union-globalmovement.

Hornbeck, J. F. (2002). 'The Argentine Finance Crisis'. CRS Report for Congress. Available at: www.iwar.org.uk/news-archive/crs/8040.pdf

Huang, P. (2009). 'China's Neglected Informal Economy: Reality and Theory'. Modern China, 35(4): 405-38.

Hu Jintao (2007). Keynote speech to the 17th National Congress of the Communist Party of China. Available at: http://english.people.com.cn/90002/92169/92187/6283147.html 
ILO (International Labour Organization) (2010). World of Work. Geneva: ILO.

ILO (2011). Statistical Update on Employment in the Informal Economy. Geneva: ILO/Department of Statistics.

Lee, S. and B.-H. Lee (2007). 'Minding the Gaps: Non-Regular Employment and Labour Market Segmentation in the Republic of Korea'. Conditions of Work and Employment Series, 19. Geneva: ILO.

NSF (National Science Foundation) (n.d.). 'Statistics'. Washington, DC: NSF. Available at: www.nsf.gov/statistics/nsf11306/appendix/pdf/tab49.pdf.

NSF (2012). National Science Board's Science and Engineering Indicators 2012. Washington, DC: NSF.

OECD (2004). Employment Outlook. Paris: OECD.

OECD (2009). Is Informal Normal? Towards More and Better Jobs in Developing Countries. Paris: OECD.

OECD (2011). Divided We Stand: Why Inequality Keeps Rising. Paris: OECD. Overview chapter available at: www.oecd.org/els/socialpoliciesanddata/49499779.pdf.

Perry, G. E., W. F. Maloney, O. S. Arias, P. Fajnzylber, A. D. Mason, J. SaavedraChanduvi (2007). Informality Exit and Exclusion. Washington, DC: World Bank.

Pires, R. (2008). ‘Promoting Sustainable Compliance: Styles of Labour Inspection and Compliance Outcomes in Brazil'. International Labour Review, 147: 199-229.

Pires, R. (2011). 'Beyond the Fear of Discretion: Flexibility, Performance, and Accountability in the Management of Regulatory Bureaucracies'. Regulation \& Governance, 5(1): 43-69. Special Issue: Sociological Citizens: Practicing Pragmatic, Relational Regulation. 
UNECSO (2009). Global Education Digest 2009. Available at:

www.uis.unesco.org/Library/Documents/ged09-en.pdf.

Wang, J. and M. Gunderson (2011). 'Minimum Wage Impacts in China: Estimates from a Prespecified Research Design, 2000-2007'. Contemporary Economic Policy, 29(3): 392-406.

WEForum (World Economic Forum) (2011). Global Competitiveness Report, 20102011. Available at: http://www3.weforum.org/docs/WEF_GCR_Report_2011$\underline{12 . p d f}$

Wen Jiabao (2011). Address by Wen Jiabao to the National People's Congress. Available at: www.asianews.it/news-en/China\%E2\%80\%99s-social-inequalities,-a$\% \mathrm{E} 2 \% 80 \% 9$ Cserious-problem\%E2\%80\%9D,-says-Wen-Jiabao-20949.html

World Bank (2013). World Development Report: Employment. Washington, DC: Oxford University Press for the World Bank.

Yaowu, W., D. Yang, and A. Park (2006). 'Measuring Informal Employment in Urban China'. Available at: www.wiego.org/sites/wiego.org/files/resources/files/YaowuMeasuring_informal_employment_in_China.pdf

\section{Table 13.1}

Shares of informal employment in non-agricultural employment in Latin America and China, selected years

\begin{tabular}{l|l|l}
\hline Countries & 1995-99/earlier 1990s & 2009/latest year \\
\hline Latin America & & \\
\hline Brazil & 60.0 & 42.2
\end{tabular}




\begin{tabular}{l|l|l}
\hline Mexico & 59.4 & 53.7 \\
\hline Argentina & 53.3 & 49.7 \\
\hline Bolivia & 63.5 & 75.1 \\
\hline Chile & 35.8 & - \\
\hline Colombia & 38.4 & 59.6 \\
\hline Costa Rica & 44.3 & 43.8 \\
\hline Dominican Republic & 47.6 & 48.5 \\
\hline Ecuador & 53.5 & 60.9 \\
\hline El Salvador & 56.6 & 66.4 \\
\hline Guatemala & 56.1 & - \\
\hline Haiti & 92.6 & - \\
\hline Honduras & 58.2 & 73.9 \\
\hline Nicaragua & - & 65.7 \\
\hline Panama & 37.6 & 43.8 \\
\hline Paraguay & 65.5 & 70.7 \\
\hline Peru & - & 70.6 \\
\hline Uruguay & - & 39.8 \\
\hline Venezuela & 46.9 & 47.5 \\
\hline China* & & $59.4(2006)$ \\
\hline Source: OECD & & \\
\hline
\end{tabular}

Source: OECD (2009: Table 2.1) for column 1; ILO (2011: Table 1) for column 2; China data for 1996 from Ghose (2005: Table 5), where I have divided the sum of informal sector + self-employed + irregular relative to total urban employment. This seems most comparable to Huang (2009: Table 1), but Table 5 shows only 3.9 per cent of wage workers listed as informal, which makes the increase even greater. * Huang (2009: Table 1); for other estimates see Yaowu, Yang, and Park (2006).

Table 13.2

Gini coefficients and rankings of labour market and related indicators of labour-related practices for selected countries and years 


\begin{tabular}{|c|c|c|c|c|c|}
\hline $\begin{array}{l}\text { Gini and measures of labour } \\
\text { market }\end{array}$ & $\begin{array}{l}\text { Gini coefficient } \\
\text { (in \%) }\end{array}$ & $\begin{array}{l}\text { Fraser Institute rank } \\
\text { of labour regulation } \\
2009\end{array}$ & $\begin{array}{l}\text { Labour } \\
\text { efficiency } \\
\text { 2011-12 }\end{array}$ & $\begin{array}{l}\text { Higher } \\
\text { education } \\
\text { 2011-12 }\end{array}$ & $\begin{array}{l}\text { Innovation } \\
2011-12\end{array}$ \\
\hline & (1) & (2) & (3) & (4) & (5) \\
\hline Median, advanced & 30.9 & 62 & 18 & 15 & 14 \\
\hline USA & 45.0 & 5 & 4 & 13 & 5 \\
\hline Germany & 27.0 & 112 & 64 & 7 & 7 \\
\hline Sweden & 23.0 & 107 & 25 & 2 & 2 \\
\hline Median, all others & 40.9 & 73 & 85 & 93 & 82 \\
\hline China & 41.5 & 103 & 36 & 58 & 29 \\
\hline Median, Latin America & 51.0 & 108 & 104 & 85 & 94 \\
\hline Argentina & 45.8 & 108 & 131 & 54 & 78 \\
\hline Bolivia & 58.2 & 124 & 140 & 95 & 106 \\
\hline Brazil & 53.9 & 130 & 83 & 57 & 44 \\
\hline Chile & 52.1 & 93 & 39 & 43 & 46 \\
\hline Colombia & 58.5 & 103 & 88 & 60 & 57 \\
\hline Costa Rica & 50.3 & 64 & 55 & 47 & 35 \\
\hline Dominican Republic & 48.4 & 75 & 104 & 99 & 122 \\
\hline Ecuador & 46.9 & 135 & 138 & 90 & 110 \\
\hline El Salvador & 46.9 & 120 & 108 & 105 & 127 \\
\hline Guatemala & 55.1 & 126 & 98 & 100 & 91 \\
\hline Guyana & 43.2 & 27 & 91 & 79 & 99 \\
\hline Haiti & 59.2 & 1 & 89 & 141 & 139 \\
\hline Honduras & 57.7 & 119 & 135 & 108 & 101 \\
\hline Jamaica & 45.5 & 32 & 80 & 85 & 94 \\
\hline Mexico & 51.7 & 104 & 114 & 72 & 63 \\
\hline Nicaragua & 43.1 & 61 & 96 & 117 & 130 \\
\hline Panama & 51.0 & 110 & 115 & 78 & 72 \\
\hline Paraguay & 53.2 & 132 & 127 & 116 & 133 \\
\hline Peru & 48.0 & 47 & 43 & 77 & 113 \\
\hline Uruguay & 42.4 & 67 & 118 & 42 & 55 \\
\hline Venezuela & 41.0 & 127 & 142 & 67 & 126 \\
\hline
\end{tabular}

Notes. The higher education index is pillar 5 . The labour market efficiency index is pillar 7, the innovation index is pillar 12. 
Source: Wikipedia for column 1 (available at: www.

en.wikipedia.org/wiki/List_of_countries_by_income_equality) and CIA GINI; these figures are close to those in Table 2.1 of Chapter 2; Fraser Institute (2009, 2011: Table 1.4) for column 2; WEForum (2011: Tables 6 and 7) for columns 3-5.

Table 13.3

Enrolments and degrees in tertiary education in USA, China, and Latin America, 2007

\begin{tabular}{lll}
\hline & Higher education enrolments & Degrees granted \\
\hline China & $25,346,000$ & $5,873,000$ \\
\hline USA & $17,759,000$ & $2,704,000$ \\
\hline Latin America in entirety & $16,737,000$ & $2,011,000$ \\
\hline Argentina & $2,202,000$ & 223,000 \\
\hline Brazil & $5,273,000$ & 820,000 \\
\hline Colombia & $1,373,000$ & 106,000 \\
\hline Mexico & $2,529,000$ & 422,000 \\
\hline
\end{tabular}

Source: UNESCO (2009: Tables 8 and 11).

Table 13.4

Percentage of workers covered by contracts and with social insurance and percentage reporting rights violations before and after the Contract Labour Law, China, selected years

\begin{tabular}{llll}
\hline & 2006 & 2009 & Change \\
\hline Contract coverage & 42.76 & 62.36 & 19.6 \\
Open-ended contract & 15.19 & 17.28 & 2.1 \\
Union existence & 16.00 & 18.57 & 2.6 \\
& & & \\
Medical insurance & 33.02 & 52.03 & 19.0 \\
Age insurance & 21.94 & 37.91 & 16.0 \\
Injury insurance & 42.91 & 56.79 & 13.9 \\
Unemployment insurance & 8.3 & 20.46 & 12.2 \\
& & & \\
Wage arrears & 8.88 & 7.22 & -1.7
\end{tabular}


